\title{
The Legal Policy on Traffic Breaches by Children Under Age/Minors
}

\author{
Wahyu Lurus Stiyo Budi ${ }^{*}$ and Bambang Tri Bawono ${ }^{* *}$ \\ ${ }^{*}$ Student of Master of Law, Universitas Islam Sultan Agung Semarang and \\ Dit Samapta Polda of Central Java, E-mail: buditiyo6@gmail.com \\ ${ }^{* *}$ Faculty of Law, Universitas Islam Sultan Agung Semarang
}

\begin{abstract}
This study aims to explain the law enforcement mechanism against traffic violations by minors. To explain the implementation of law enforcement in relation to a sense of justice for the parties concerned. This study uses a normative juridical approach. This type of research is a case/field research. Case/field research is research that aims to study intensively the background of the current state and the environmental interactions of an object. So that analysis and facts can be obtained carefully, thoroughly, and clearly about the process of resolving cases of traffic violations against minors. The results showed that law enforcement against traffic violations by minors, namely through diversion, namely at the level of investigation, prosecution, and examination of cases of children in district courts must be pursued by Diversion, provided that the criminal act is committed; Is threatened with imprisonment for a maximum of 7 (seven) years and does not constitute a repeat offense. The criminal sanctions that are applied to traffic violations of minors, namely the judge's decision based on Act No. 3 of 1997 in the Juvenile Criminal Justice System Bill in the form of crimes or actions. the perpetrator is still subject to punishment for the incident through the applicable procedures according to the Juvenile Criminal Court Law.

Keywords: Minors; Traffic Offenses; Criminal.
\end{abstract}

\section{Introduction}

The public expects legal certainty, because with legal certainty, the community will be more orderly. Law has the task of creating legal certainty because it aims at public order. On the other hand, people expect benefits in implementing or enforcing the law. Law is for humans, so law enforcement or law enforcement must provide benefits or benefits to society. Do not let it be that because the law is enforced or enforced, there will be unrest in the community. ${ }^{1}$

The public has a strong interest that in the implementation or enforcement of the law, justice is considered. In implementing or enforcing the law must be fair. Law is not synonymous with justice. The law is general, binding everyone, generalizing. Whoever stole must be punished: everyone who stole must be punished, regardless of who stole.

If in enforcing the law only legal certainty is concerned, other elements are sacrificed. Likewise, if what you pay attention to is only benefit, then legal certainty and justice are sacrificed and so on. "In enforcing the law, there must be a compromise between the three elements. The three elements must receive balanced proportional

\footnotetext{
${ }^{1}$ Poernomo, Bambang. (2001). Kapita Selekta of the Criminal Justice System. Jayabaya University. p. 3
} 
attention. But in practice it is not always easy to work out a proportionally balanced compromise between the three elements". ${ }^{2}$

Nowadays, it is not only adults who commit traffic violations but also underage schoolchildren, their level of awareness in traffic is still low. It can be seen from the Police data that there is still a high number of junior high and high school students who violate traffic. Responding to this problem parents should be dominant, in many cases we find it so easy for parents to allow their children to drive vehicles and not limited to the environment where the child lives. But it is also permissible to bring a school vehicle, even though from any point of view it is not justified for a student to drive a vehicle because they are not old enough and do not have a driving license (SIM). The teachers should be firm in addressing the problem that if there are students who do not comply with school regulations, they will be subject to sanctions or need to form a special team with the Police to monitor the rules issued by the school. Another concrete action that can be done is announcing through the media the most traffic violators of school students.

The total traffic offenders in 2019 based on data from Discipline operation Jaya increased by $63.29 \%$ with a total of 167,928 offenders. ${ }^{3}$ This condition is exacerbated, namely the number of traffic offenders to minors has increased sharply and is even more dominant. Data from various reports states that underage motorcyclists dominate the number of offenders in Discipline operation Progo 2019 in Kulonprogo. Of the total 6,365 offenders, 3,220 of them were children and adolescents under the age of $16 .{ }^{4}$ Other data found that the violations that were mostly prosecuted were those committed by minors. There were 56,192 cases of prosecution during Discipline operation Semeru 2019. This number is up about 50 percent over the previous year which was only 37,513 cases. $^{5}$

Hence the government and police are responsible for ensuring the safety of Traffic and Road Transportation (LLAJ), but the government's responsibility is only oriented as stated in Act No. 22 of 2009 concerning Road Traffic and Transportation (LLAJ Law) Article 203 paragraph (1), namely, the government is responsible for ensuring road traffic and transportation. And paragraph (2), in order to guarantee the safety of road traffic and transportation as referred to in paragraph (1), a national general plan for road traffic and transportation safety shall be implemented, which includes: a. preparation of a national program for road traffic and road transportation safety

\footnotetext{
${ }^{2}$ Mustafa, Abdullah. (1982). Legal Awareness And Legal Certainty.Jakarta: Rajawali. p.67-68

3 CNN. Traffic Violators in Patuh Jaya Operation Rise 63 Percent. (2019). From https://www.cnnindonesia.com/nasional/20190913230839-12-430416/pelanggar-lalu-lintas-padaoperasi-patuh-jaya-naik-63-persen accessed on July 23, 2020

${ }^{4}$ Harianjogja.com. (2018). Underage Drivers Dominate Traffic Violations in Kulonprogo. https://jogjapolitan.harianjogja.com/read/2019/09/14/514/1018569/pengendara-di-bawah-umurdominasi-pelanggaran-lalu-lintas-di-kulonprogo accessed on July 23, 2020

${ }^{5}$ Republika.Co.Id, Surabaya. (2017). Minors Dominate Traffic Offenses. https://nasional.republika.co.id/berita/pxp6z4335/anak-di-bawah-umur-dominasi-pelanggaran-lalu-

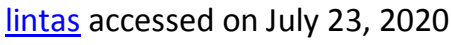


activities. b. provision and maintenance of road traffic and road transportation safety facilities and equipment c. study of road traffic and transportation safety issues. ${ }^{6}$

Based on the background above, the objectives of this study include 1) Knowing and analyzing the application of the law to traffic offenses committed by minors; and 2) Knowing and analyzing the efforts and roles of police officers in overcoming traffic violations by minors.

\section{Research methods}

The approach method used in this research is the normative juridical approach method. Using the type of case research/field research. Case/field research is research that aims to study intensively the background of the current state and the environmental interactions of an object. ${ }^{7}$ So that analysis and facts can be obtained carefully, thoroughly, and clearly about the process of resolving cases of traffic violations against minors. Using the type of primary data obtained in the form of facts or information on the results of research directly at the research location and is the result of interviews with police or investigators dealing with child traffic violations and secondary data in the form of primary legal materials, secondary legal materials and tertiary legal materials. The technique of collecting data is through Library Research, namely library research by carrying out an inventory of laws and regulations, documents and literature related to the problems studied and also by the Field Research method, namely field research, which is conducted through interviews with several respondents, in this case the police or investigators who handle traffic violations by minors. The analytical method uses inductive logic, to draw conclusions from cases that are specific and individual into 6 general things". The data obtained from literature and field studies are analyzed qualitatively and are linked between primary and secondary legal materials related to the problem. The results of the analysis are then presented based on cases in the field, to be compiled as a conclusion to the existing problems. ${ }^{8}$

\section{Result and Discussion}

\subsection{The application of the law against traffic offenses committed by minors}

Actions usually carried out in the field include the first: omission of traffic violations. It is very commonplace to become a daily sight that the number of traffic violators is countless. Most of these offenders were not prosecuted by the second police: less than maximal repression. There are several reasons why officers are not optimal towards traffic offenders, namely violators' mistakes are still usually forgiven, officer take advantage of these violations. Third: maximum action. In several police cases,

\footnotetext{
${ }^{6}$ Hamzah, Muhammad Dani. Law Enforcement in the Criminal Case of Traffic Accidents which Causes the Loss of People's Lives. Journals of law enforcement Volume 1 No. March 1, 2018: 43 - 52.

${ }^{7}$ Mamudji, Sri and Soerjono Soekanto. (2001). Normative Legal Research (A Brief Overview). Jakarta: Rajawali Pers. p. 13-14

${ }^{8}$ Usman, Husaini., et al. (2004). Social Research Methods. Jakarta: PT Bumi Aksara. p.218
} 
the courage to take firm action was motivated by several factors, namely: blatant offenders, underestimating the appeal of officers. ${ }^{9}$

The criminal sanctions imposed on children must be based on truth, justice and the welfare of the child. Imposing a crime or action that must be responsible and beneficial for the child. The judge is obliged to consider the condition of the child, the condition of the house, the state of the environment, and the report of the social adviser. ${ }^{10}$

Children who are not yet 12 (twelve) years old, even though they have committed a criminal act, cannot be brought to the juvenile court hearing. This is based on sociological considerations, that a child who is not yet 12 (twelve) years old cannot be held accountable for his actions. Children who are not yet 12 (twelve) years old and have committed a criminal act cannot be subject to criminal sanctions or sanctions. To determine whether a child will be subject to punishment or action, the judge considers the severity of the criminal offense. Besides, it is also considered; the condition of the child, the condition of the household of the parents/guardians/foster parents, the relationship between family members, and the state of the environment. In addition, the judge also pays attention to the social advisory report. ${ }^{11}$

\subsection{The efforts of the police officers in tackling traffic violations committed by minors}

Regarding Traffic violations as regulated in Act No. 22 of 2009 concerning Road Traffic and Transportation Article 1 that Road Traffic and Transportation is a unitary system consisting of Traffic, road transportation, Traffic and road transportation networks, Traffic infrastructure. Traffic and road transportation, vehicles, drivers, road users, and their management.

Traffic Violations still often occur, ironically, violations are predominantly committed by students in uniform, their lack of knowledge of traffic regulations makes them often commit violations and also their age is not sufficient to have a SIM (driving license), which is one of the requirements for completing driving. ${ }^{12}$

In terms of overcoming the behavior of school children who are not obedient and sometimes committing traffic violations because they are not old enough to have a driving license (SIM), the apparatus in this case the Traffic Police must make efforts. As stated by EH Sutherland and Cressey, there are two methods used, namely: ${ }^{13}$

- Preventive measures

Preventive prevention of crimes is carried out to prevent the occurrence or occurrence of crimes for the first time. Preventing crime is better than trying to educate criminals to be better again, as the motto in criminology is that efforts to

\footnotetext{
${ }^{9}$ Moeljatno. (2008). Principles of Criminal Law. Jakarta: Rieneka Cipta. p.53

${ }^{10}$ Ali, Achmad. (1982). Revealing the Veil of Law. Jakarta: Chandra Pratama

${ }^{11}$ Child Protection and Act No. 11 of 2012 concerning the Child Criminal Justice System, chapter I, article 1 paragraph (3)

${ }^{12}$ Sitepu, Desy Kartika Caronina. Juridical Analysis of Perpetrators of Traffic Violations by Children in Simalungun Regency. Scientific Journal "Advocacy" Vol. 08. No. 01 March 2020

${ }^{13}$ Law of the Republic of Indonesia, Act No. 22 of 2009, concerning Traffic and Road Transportation of the Republic of Indonesia,
} 
correct criminals need to be considered and directed so that repeat crimes do not occur. It stands to reason that preventive efforts are prioritized because preventive efforts can be carried out by anyone without special expertise and economics. $^{14}$

The efforts made by the police officers in overcoming Traffic violations committed by minors are as follows:

- Conducting socialization of information on orderly traffic in schools

- Participate in carrying out school activities, namely the police officers who become the Inspector for Ceremonies in schools

- Cultivate students to become school security patrols

- Increase knowledge of orderly traffic and race quiz about traffic

- Law enforcement: enforcing control of students who have not met the driving requirements in collaboration with the education office and the school

- Repressive measures

A repressive measure is a conceptual crime prevention effort taken after a crime has occurred. Countermeasures with repressive measures are intended to take action against the perpetrators of crime in accordance with their deeds and to correct them again so that they are aware that the actions they have committed are illegal and detrimental to society, so they will not repeat them and other people will also not do so considering the very heavy sanctions they will bear. ${ }^{15}$

If in an attempt to traffic violations committed by minors in the city of Jeneponto by preventive means there are still many Traffic violations, in this case the police apparatus must make repressive measures to prosecute school children who commit violations so that there is a clear effect. The child who commits the violation and does not repeat the act again, namely the police apparatus commits: ${ }^{16}$

- A ticket is proof of violation. The function of the ticket itself is as an invitation to a child who commits a traffic violation to attend a trial in a district court, as well as evidence of confiscation of goods confiscated by the police against the child who violates

- The confiscation was carried out because the school children did not have a SIM (driving license) seeing that they were not old enough to have a SIM

- Reprimands are made to children who violate traffic but promise not to violate again by making a written statement that it will not violate again.

The role of the police apparatus in traffic violations committed by minors, namely:

- Carry out routine policing activities in the form of operations in schools

- Put up traffic advisory banners

- Spread out brochures about traffic.

\footnotetext{
${ }^{14}$ A, Amriani. Review of Traffic Violations by Minors in the Jeneponto Police Area. Article. Faculty of Sharia and Law of the State Islamic University Alauddin Makassar 2017

${ }^{15}$ Fithry, Abshoril. Judicial Review of Act No. 22 of 2009 concerning Road Traffic and Transportation to the Level of Awareness and Compliance of the Sumenep Community. Journal of "JENDELA HUKUM" FACULTY OF LAW UNIJA. Volume I Number 1 April 2014.

${ }^{16}$ Law of the Republic of Indonesia, Act No. 22 of 2009, concerning Traffic and Road Transportation of the Republic of Indonesia,
} 
What is the form and role of the police apparatus in overcoming the problem of Traffic violations committed by minors is the police apparatus' way of minimizing the occurrence of traffic violations because based on the facts, most of the traffic accidents are caused by Traffic violations.

Law enforcers are officials who carry out the process of efforts to uphold or function legal norms in a real way as a code of conduct in traffic or legal relations in the life of society and the state, to guarantee and ensure the enforcement of the law. Law enforcers have positions and roles. Therefore, a law enforcer who has a certain position automatically has the authority to do something based on his office. Law enforcers are role models in society, who should have certain abilities, in accordance with the aspirations of society. They must be able to communicate and get understanding from the group, in addition to carrying out or playing a role that is acceptable to the community. If the laws and regulations-The legislation is good, but if the mentality of the law enforcer is not good, it will have an effect on the law enforcement system. Rules that are already good but not supported by enforcement officials are quite difficult to raise public awareness. Regulations that are supported by supervision by the authorities will lead to better compliance than those that are communicated but left uncontrolled. The law enforcer referred to in this research is the police, especially the police who handle the traffic sector. ${ }^{17}$

\section{Closing}

\subsection{Conclusion}

The application of the law on traffic violations committed by minors, namely:

- Omission of violations: The number of traffic offenders has not been counted. The offenders were mostly not prosecuted by the police.

- Actions that are not optimal: violators' mistakes are still usually forgiven, officers take advantage of these violations.

- Maximum action: blatant offenders, underestimating the appeal of the officer, orders from the commander that all Traffic offenders at certain locations and places must be dealt with firmly (given the maximum penalty)

\subsection{Suggestion}

The efforts and roles made by police officers in overcoming traffic violations committed by minors, namely:

- Preventive efforts, this effort is the first step taken by police officers to tackle the occurrence of traffic violations committed by school children, namely by disseminating information on orderly traffic in schools, so that they understand about driving properly and correctly.

\footnotetext{
${ }^{17}$ Asmara, Dewa Putu Tagel Ni Ketut Sri Ratmini I Made Yudi. Law Enforcement against Children Using Motorbikes. VYAVAHARA DUTA Volume XIV, No.1, March 2019.
} 
- Repressive measures, these efforts are taken by police officers to take direct action against minors who commit traffic violations and are useful for giving a clear effect on minors who commit violations.

\section{References}

\section{Books:}

Ali, Achmad. (1982). Revealing the Veil of Law. Jakarta: Chandra Pratama

Mamudji, Sri and Soerjono Soekanto. (2001). Normative Legal Research (A Brief Overview). Jakarta: Rajawali Pers. p. 13-14

Moeljatno. (2008). Principles of Criminal Law. Jakarta: Rieneka Cipta.

Mustafa, Abdullah. (1982). Legal Awareness and Legal Certainty.Jakarta: Rajawali.

Poernomo, Bambang. (2001). Kapita Selekta of the Criminal Justice System. Jayabaya University.

Usman, Husaini., et al. (2004). Social Research Methods. Jakarta: PT Bumi Aksara.

\section{Journals:}

A, Amriani. Review of Traffic Violations by Minors in the Jeneponto Police Area. Article. Faculty of Sharia and Law of the State Islamic University Alauddin Makassar 2017

Asmara, Dewa Putu Tagel Ni Ketut Sri Ratmini I Made Yudi. Law Enforcement against Children Using Motorbikes. VYAVAHARA DUTA Volume XIV, No.1, March 2019.

Fithry, Abshoril. Judicial Review of Act No. 22 of 2009 concerning Road Traffic and Transportation to the Level of Awareness and Compliance of the Sumenep Community. Journal of "JENDELA HUKUM" FACULTY OF LAW UNIJA. Volume I Number 1 April 2014.

Hamzah, Muhammad Dani. Law Enforcement in the Criminal Case of Traffic Accidents which Causes the Loss of People's Lives. Journals of law enforcement Volume 1 No. March 1, 2018: 43 - 52.

Sitepu, Desy Kartika Caronina. Juridical Analysis of Perpetrators of Traffic Violations by Children in Simalungun Regency. Scientific Journal "Advocacy" Vol. 08. No. 01 March 2020

\section{Regulation}

Act No. 22 of 2009 concerning Traffic and Road Transportation

Act No. 11 of 2012 concerning the Child Criminal Justice System, chapter I, article 1 paragraph (3)

\section{Internet:}


CNN. Traffic Violators in Patuh Jaya Operation Rise 63 Percent. (2019). From https://www.cnnindonesia.com/nasional/20190913230839-12430416/pelanggar-lalu-lintas-pada-operasi-patuh-jaya-naik-63-persen accessed on July 23, 2020

Harianjogja.com. (2018). Underage Drivers Dominate Traffic Violations in Kulonprogo. https://jogjapolitan.harianjogja.com/read/2019/09/14/514/1018569/penge ndara-di-bawah-umur-dominasi-pelanggaran-lalu-lintas-di-kulonprogo accessed on July 23, 2020

Republika.Co.Id, Surabaya. (2017). Minors Dominate Traffic Offenses. https://nasional.republika.co.id/berita/pxp6z4335/anak-di-bawah-umurdominasi-pelanggaran-lalu-lintas accessed on July 23, 2020 